\section{Os Elementos em Ciências Uma Viagem pela Tabela Periódica}

\section{Sobre o Livro}

A Assembleia Geral das Nações Unidas proclamou o ano de 2019 como o Ano Internacional da Tabela Periódica dos Elementos Químicos (IYPT 2019) para comemorar os 150 anos do seu estabelecimento. No âmbito destas comemorações, o Departamento de Química e Bioquímica de Ciências ULisboa editou o livro "Os Elementos em Ciências - Uma viagem pela Tabela Periódica" no qual participaram 92 autores, nomeadamente professores e investigadores de vários Departamentos e Unidades de Investigaçãa de Ciências, bem como investigadores de outras instituições com as quais Ciências colabora. Neste livro coligiram-se 73 textos, sobre 88 elementos químicos, em que alguns, como por exemplo o nitrogénio e o carbono, são abordados em mais do que um texto, traduzindo a diversidade de abordagens sobre estes elementos em várias áreas da Ciência. Este livro tem como objetivo a divulgação da investigação desenvolvida em Ciências ULisboa centrada em vários elementos químicos e o impacto dessa investigação na sociedade. Nessa medida, tem como público-alvo investigadores, docentes e alunos de todos os graus de ensino e o público em geral.

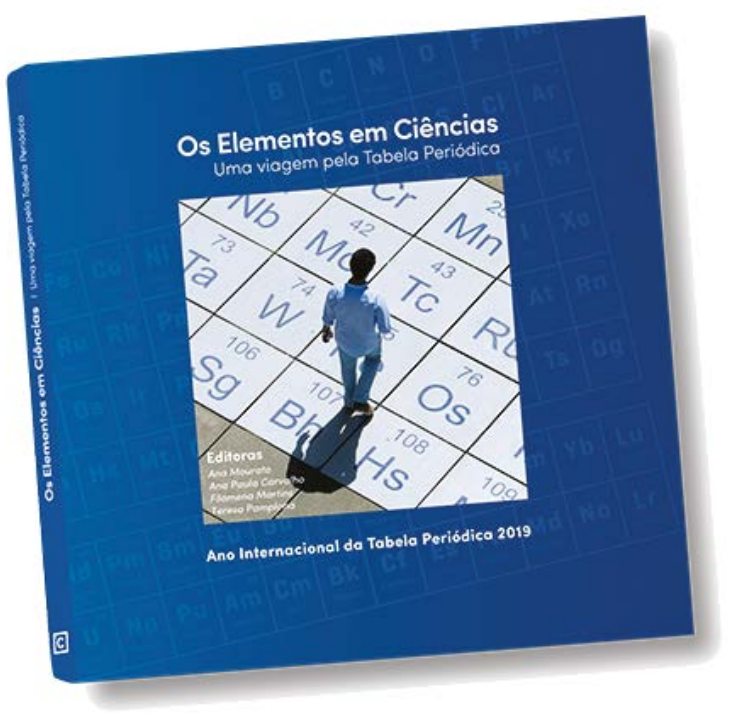

Ciências ULisboa

ISBN: 978-972-9348-22-8 (impressão)

978-972-9348-21-1 (e-book)

Editoras: Ana Mourato, Ana Paula Carvalho,

Filomena Martins e Teresa Pamplona

\section{Sobre as Editoras}

As editoras são docentes e investigadoras no Departamento de Química e Bioquímica de Ciências ULisboa, com áreas de especialização distintas, nomeadamente Química-Física, Química Orgânica e Química dos Materiais, e gosto pela comunicação de Ciência. 